\title{
KEJADIAN BERAT BADAN LAHIR RENDAH DI DESA TINELO KABUPATEN GORONTALO DAN FAKTOR YANG MEMENGARUHINYA
}

\author{
(Incidence of low birth weight in Tinelo Village, Gorontalo Regency \\ and its influencing factor)
}

\author{
Nuryani $^{1 *}$, Rahmawati ${ }^{2}$ \\ 'Program Studi Ilmu Gizi, Fakultas Kesehatan Masyarakat, Universitas Gorontalo, Gorontalo 96211 \\ ${ }^{2}$ Program Studi Ilmu Kesehatan Masyarakat, Fakultas Kesehatan Masyarakat, Universitas Gorontalo,
}

Gorontalo 96211

\begin{abstract}
The aim of this study was to assess the association of maternal age, education level and family income with low birth weight $(L B W)$. The study was an observational study with cross sectional design. The number of subject were 60 children under five years old obtained by accidental sampling. The results showed that $18.3 \%$ of mothers gave birth at high risk age ( $\leq 19$ years old and $\geq 35$ years old), $43.3 \%$ mothers had education level of senior high school, 96.7\% mothers were housewives, $54.2 \%$ father's occupation was self-employed, $71.7 \%$ of family income per month was under minimum regional wage. $16.7 \%$ of infants with LBW. The bivariate analysis showed that the incidence of low birth weight was not associated with maternal age ( $p=0.371)$, there was no correlation between the incidence of low birth weight with family income per month $(p=0.709)$ and there was correlation between low birth weight with mother education level $(p=0.017)$. It can be concluded that maternal age and family income per month was not associated with $L B W$, while education level was associated with $L B W$.
\end{abstract}

Keywords: education, income, low birth weight, maternal age

\begin{abstract}
ABSTRAK
Penelitian ini bertujuan menilai hubungan usia ibu melahirkan, pendidikan dan pendapatan dengan kejadian berat badan lahir rendah (BBLR). Jenis penelitian adalah observasional dengan rancangan studi potong lintas. Jumlah subjek dalam penelitian ini adalah 60 balita diperoleh dengan cara accidental sampling. Hasil penelitian menunjukkan bahwa $18,3 \%$ ibu melahirkan pada usia berisiko $(\leq 19$ tahun dan $\geq 35$ tahun), 43,3\% tingkat pendidikan ibu balita adalah Sekolah Menengah Pertama, 96,7\% merupakan ibu rumah tangga, 54,2\% pekerjaan ayah sebagai wiraswasta, $71,7 \%$ pendapatan keluarga per bulan dibawah upah minimum regional. Jumlah balita BBLR 16,7\%. Analisis bivariat menunjukkan kejadian BBLR tidak berhubungan dengan umur ibu melahirkan $(\mathrm{p}=0,371)$, tidak terdapat hubungan antara kejadian BBLR dengan pendapatan per bulan $(\mathrm{p}=0,709)$, terdapat hubungan antara BBLR dengan tingkat pendidikan ibu $(\mathrm{p}=0,017)$. Kesimpulan tidak ditemukan hubungan usia ibu hamil dan pendapatan keluarga per bulan dengan BBLR, sementara tingkat pendidikan berhubungan dengan kejadian BBLR.
\end{abstract}

Kata kunci: BBLR, pendapatan, pendidikan, umur ibu

\section{PENDAHULUAN}

Berat badan lahir rendah (BBLR) merupakan berat badan lahir bayi di bawah $2.500 \mathrm{~g}$ tanpa memperhatikan umur kehamilan. Lebih dari 20 juta bayi di dunia, sekitar 16,0\% lahir dengan BBLR dan $95,6 \%$ bayi BBLR lahir di negara berkembang (Mduduzin et al. 2010). Prevalensi BBLR di negara berpendapatan rendah lebih besar dua kali lipat dibandingkan negara yang berpendapatan menengah. Di Zimbabwe prevalensi BBLR bervariasi menurut kelompok jenis kelamin yakni $17 \%$ pada perempuan dan $13,0 \%$ pada laki-laki (Mduduzin et al. 2010). Prevalensi bayi dengan berat badan lahir rendah di Indonesia berdasarkan data hasil Riset Kesehatan Dasar sedikit mengalami penurunan dari $11,1 \%$ tahun 2010 menjadi 10,2\% tahun 2013 dengan seba-

\footnotetext{
"Korespondensi: Telp: +6285299266180, Surel: nuryanigz@gmail.com
} 
ran yang cukup bervariasi pada masing-masing kabupaten. Angka kejadian BBLR di Provinsi Gorontalo (13,2\%), lebih tinggi dibandingkan angka Nasional (Riskesdas 2013).

BBLR erat kaitannya dengan kesakitan dan kematian neonatal, gizi kurang pada awal kehidupan, perlambatan pertumbuhan, gangguan perkembangan kognitif dan motorik (Demelash et al. 2015; Vir 2011; Datar \& Jacknowitz 2009). BBLR juga memengaruhi terjadinya penyakit kronik dimasa akan datang seperti diabetes, hipertensi dan penyakit jantung. Bayi BBLR meningkatkan risiko kematian 40 kali dibandingkan bayi lahir normal (Goldenberg \& Culhane 2007). Di negara berkembang, mayoritas bayi yang BBLR dilahirkan aterm (cukup bulan) dan sudah menderita retardasi pertumbuhan intrauteri sebagai akibat dari maternal stunting dan gizi kurang yang terjadi sebelum dan selama kehamilan atau akibat infeksi (Goldenberg \& Culhane 2007). Sementara kejadian stunting sangat erat kaitannya dengan status sosial ekonomi (Mauludyani et al. 2012). Komplikasi perinatal dan neonatal lebih tinggi pada bayi dengan BBLR yang akan berpengaruh merugikan pada perkembangan motorik, mental dan intelligence quotient (IQ) yang lebih rendah pada anak. Dampak BBLR lebih besar pada anak-anak di negara berkembang, karena sebagian besar anak dengan BBLR dari keluarga tingkat kesejahteraan rendah banyak dijumpai di negara berkembang. Selain itu menurut hipotesis Barker, BBLR berkaitan dengan peningkatan angka prevalensi penyakit jantung koroner dan kelainan berkaitan stroke, hipertensi dan diabetes tipe 2, efek ini mungkin merupakan konsekuensi dari programming janin ketika mengalami stimulus atau cedera dalam periode awal kehidupan yang kritis dan sensitif memberikan efek yang parmanen terhadap anatomi, fisiologi, dan metabolisme. Hal ini berkaitan dengan adaptasi yang timbul ketika pasokan zat gizi maternal ke plasenta tidak berhasil mengimbangi kebutuhan janin. Tingginya angka BBLR bisa memengaruhi kualitas sumber daya manusia di masa depan. Oleh karena itu berbagai upaya perlu dilakukan untuk menurunkan angka BBLR (Gibney et al. 2005).

Faktor yang mempengaruhi BBLR beragam sesuai perbedaan lingkungan. Berdasarkan kerangka konsep UNICEF menunjukkan bahwa status sosial ekonomi merupakan akar masalah dari masalah gizi. Status sosial ekonomi juga berhubungan dengan kejadian BBLR (Demelash et al. 2015). Di negara dengan pendapatan rendah, BBLR berkaitan dengan lingkungan hidup yang buruk yang menimbulkan pengaruh secara independen pada perkembangan anak (Gibney et al. 2005). Hasil penelitian Demelash et al. (2015) menunjukkan bahwa usia ibu melahirkan $<20$ tahun berisiko 3,0 kali melahirkan BBLR, pendapatan per bulan $<26$ dollar berisiko 3,8 kali melahirkan BBLR dan pendidikan formal yang rendah berisiko 6 kali melahirkan BBLR. Sementara itu penelitian lain yang dilakukan oleh Zahed et al. (2004) menyatakan bahwa ibu hamil yang memiliki umur diatas 35 tahun berisiko 2,3 kali melahirkan BBLR. Hasil penelitian di Nepal mendapatkan bahwa terdapat hubungan antara tingkat pendidikan ibu dengan kejadian BBLR (Joshi et al. 2007). Penelitian yang dilakukan di kota Sumenep juga menemukan bahwa pendidikan ibu rendah 4,4 kali berisiko melahirkan BBLR (Festy 2011).

Berfokus dalam upaya pencegahan BBLR, sejumlah faktor risiko perlu dipahami. Hubungan antara gizi maternal dan faktor sosial ekonomi dapat dikaji lebih lanjut, untuk memberikan dasar dalam pengembangan intervensi yang bertujuan untuk mempelajari faktor risiko dari BBLR. Tujuan penelitian ini adalah menilai hubungan usia ibu melahirkan, pendidikan ibu dan pendapatan keluarga dengan kejadian BBLR di desa Tinelo, Kabupaten Gorontalo.

\section{METODE}

\section{Desain, tempat, dan waktu}

Jenis penelitian adalah observasional dengan rancangan studi potong lintas untuk menilai hubungan usia ibu melahirkan dan status sosial ekonomi dengan kejadian BBLR. Lokasi penelitian dilakukan di Desa Tinelo, Kabupaten Gorontalo. Penelitian dilaksanakan pada bulan April-Mei 2016.

\section{Jumlah dan cara pengambilan subjek}

Populasi dari penelitian ini adalah seluruh balita yang berdomisili di Desa Tinelo. Jumlah subjek dalam penelitian ini yaitu 60 balita dan penarikan subjek penelitian dilakukan secara $a c$ cidental sampling. Pengambilan balita sebagai subjek penelitian adalah balita yang berdomisili dan berada di lokasi penelitian saat pengumpulan data berlangsung. Apabila responden, baik orang tua maupun keluarga balita tidak bersedia memberikan informasi saat pendataan maka balita tersebut tidak dimasukkan sebagai subjek penelitian.

\section{Jumlah dan cara pengumpulan data}

Pengumpulan data dilakukan melalui wawancara dengan responden menggunakan kue- 
sioner. Responden adalah mereka yang tinggal dan dekat dengan subjek penelitian yakni orang tua ataupun nenek dari Balita. Data BBLR diperoleh dari pencatatan buku KIA Balita dan pencatatan di Posyandu. Kategori variabel penelitian meliputi umur ibu melahirkan kategori berisiko jika kurang 20 tahun dan diatas 35 tahun, variabel pendapatan dikategorikan kurang jika total pendapatan per bulan di bawah upah minimum regional Kabupaten Gorontalo yakni 1,8 juta, sementara variabel pendidikan dikategorikan rendah jika pendidikan formal ibu kurang dari sembilan tahun. Variabel pekerjaan ibu dikategorikan bekerja jika ibu memiliki pekerjaan selain ibu rumah tangga dan ketagori ibu tidak bekerja jika ibu hanya sebagai ibu rumah tangga.

\section{Pengolahan dan analisis data}

Analisis data dilakukan secara univariat dan bivariat. Analisis univariat dilakukan untuk melihat gambaran dari frekuensi masing-masing variabel yakni umur ibu, tingkat pendidikan ibu, pendapatan keluarga per bulan. Analisis bivariat dilakukan untuk menilai hubungan antara variabel. Uji statistik yang digunakan adalah chi square test dengan aplikasi SPSS 16.

\section{HASIL DAN PEMBAHASAN}

Karakteristik orang tua balita dalam penelitian ini ditunjukkan pada Tabel 1. Sebagian besar subjek adalah ibu berumur 20-34 tahun pada saat melahirkan $(80,0 \%)$ dan hanya sedikit ibu yang melahirkan saat berumur $\leq 19$ tahun $(5,0 \%)$. Tingkat pendidikan Sekolah Menengah Atas (SMA) termasuk kategori jumlah terbanyak yakni 26 orang $(43,3 \%)$, sementara kategori pendidikan terendah adalah tidak tamat Sekolah Dasar (SD) yakni 2 orang (3,3\%). Pekerjaan ibu terbanyak adalah ibu rumah tangga (IRT) yakni 58 orang $(96,7 \%)$, sementara status pekerjaan ayah terbanyak adalah wiraswasta yakni 32 orang $(54,2 \%)$ dan terendah adalah PNS yakni hanya 6 orang $(10,2 \%)$. Pendapatan per bulan paling banyak di bawah upah minimum Kabupaten Gorontalo yakni $<$ Rp 1,8 juta sebanyak 43 orang $(71,7 \%)$.

Karakteristik balita desa Tinelo dalam penelitian ini ditunjukkan pada Tabel 2. Sebagian besar subjek adalah balita perempuan $(63,4 \%)$. Kebanyakan subjek merupakan anak kedua $(40,0 \%)$. Sebanyak 56 subjek $(93,3 \%)$ proses persalinannya dibantu oleh bidan dan masih ada 4 subjek $(6,7 \%)$ yang proses persalinannya dibantu oleh dukun. Sebanyak 53 subjek (88,3\%) lahir dengan cara persalinan normal dan 7 sub-
Tabel 1. Karakteristik orangtua balita di Desa Tinelo, Kabupaten Gorontalo

\begin{tabular}{lcc}
\hline \multicolumn{1}{c}{ Karakterisitk } & \multicolumn{2}{c}{ Jumlah } \\
\cline { 2 - 3 } & $\mathrm{n}$ & $\%$ \\
\hline Umur ibu saat melahirkan & 3 & 5,0 \\
$\leq 19$ tahun & 48 & 80,0 \\
20-34 tahun & 9 & 15,0 \\
$\geq 35$ tahun & & \\
Pendidikan ibu & 2 & 3,3 \\
$\quad$ Tidak tamat sekolah dasar & 9 & 15,0 \\
Sekolah dasar & 15 & 25,0 \\
Sekolah menengah pertama & 26 & 43,3 \\
Sekolah menengah atas & 8 & 13,4 \\
$\quad$ Diploma/Sarjana & & \\
Pekerjaan ibu & 2 & 3,3 \\
$\quad$ PNS & 58 & 96,7 \\
IRT & & \\
Pekerjaan ayah & 6 & 10,2 \\
PNS & \\
Wiraswasta & 32 & 54,2 \\
Buruh & 21 & 35,6 \\
Pendapatan per bulan & & \\
$\quad<$ Rp 1,8 juta & 43 & 71,7 \\
$\geq$ Rp 1,8 juta & 17 & 28,3 \\
\hline
\end{tabular}

Tabel 2. Karakteristik balita di Desa Tinelo, Kabupaten Gorontalo

\begin{tabular}{lcc}
\hline \multirow{2}{*}{ Karakterisitk } & \multicolumn{2}{c}{ Jumlah } \\
\cline { 2 - 3 } & $\mathrm{n}$ & $\%$ \\
\hline Jenis kelamin & 22 & 36,6 \\
$\quad$ Laki-laki & 38 & 63,4 \\
Perempuan & & \\
Status bayi & 18 & 30,0 \\
$\quad$ Anak pertama & 24 & 40,0 \\
Anak kedua & 18 & 30,0 \\
Anak ketiga & & \\
Pembantu persalinan & 56 & 93,3 \\
Bidan & 4 & 6,7 \\
Dukun & & \\
Cara lahir & 53 & 88,3 \\
$\quad$ Normal & 7 & 11,7 \\
$\quad$ Sexcio caesare & & \\
Kepemilikan KMS balita & 44 & 73,3 \\
$\quad$ Ada & 16 & 26,7 \\
Tidak ada & & \\
Berat lahir & 10 & 16,7 \\
$\quad$ BBLR & 50 & 83,3 \\
Tidak BBLR & & \\
\hline
\end{tabular}

jek $(11,7 \%)$ dengan sectio caesarea. Berdasarkan laporan kepemilikan KMS hanya 44 subjek (73,3\%) yang memiliki KMS. Sebanyak 10 subjek $(16,7 \%)$ mengalami BBLR.

Analisis bivariat yang menilai hubungan antara kejadian BBLR dengan variabel umur ibu, pendapatan keluarga per bulan dan pendidikan ibu ditunjukkan pada Tabel 3. 
Tabel 3. Analisis hubungan antara kejadian BBLR dengan umur ibu melahirkan, pendapatan keluarga dan tingkat pendidikan ibu di Desa Tinelo, Kabupaten Gorontalo

\begin{tabular}{|c|c|c|c|c|c|c|c|}
\hline \multirow{3}{*}{ Variabel } & \multicolumn{4}{|c|}{ Kategori BBLR } & \multirow{2}{*}{\multicolumn{2}{|c|}{ Total }} & \multirow{3}{*}{$\mathrm{p}$} \\
\hline & \multicolumn{2}{|c|}{ BBLR } & \multicolumn{2}{|c|}{ Normal } & & & \\
\hline & $\mathrm{n}$ & $\%$ & $\mathrm{n}$ & $\%$ & $\mathrm{n}$ & $\%$ & \\
\hline \multicolumn{8}{|l|}{ Umur } \\
\hline Berisiko & 3 & 27,3 & 8 & 72,7 & 11 & 18,3 & 0,371 \\
\hline Tidak berisiko & 7 & 14,3 & 42 & 85,7 & 49 & 81,7 & \\
\hline \multicolumn{8}{|l|}{ Pendapatan } \\
\hline Kurang & 8 & 18,6 & 35 & 81,4 & 43 & 71,6 & 0,709 \\
\hline Cukup & 2 & 11,8 & 15 & 88,2 & 15 & 28,4 & \\
\hline \multicolumn{8}{|l|}{ Pendidikan } \\
\hline Rendah & 5 & 45,5 & 6 & 54,5 & 11 & 18,3 & 0,017 \\
\hline Tinggi & 5 & 10,2 & 44 & 89,8 & 49 & 81,7 & \\
\hline
\end{tabular}

Ibu melahirkan bayi BBLR dengan umur berisiko sebanyak $27,3 \%$, sementara yang melahirkan bayi tidak BBLR dengan umur tidak berisiko $85,7 \%$. Hasil uji chi square menunjukkan nilai $p=0,371$, hal ini menunjukkan bahwa umur ibu tidak berhubungan dengan kejadian BBLR. Hasil penelitian ini sejalan dengan hasil penelitian Mahayana et al. (2015) di Padang, dimana tidak terdapat hubungan antara usia ibu dengan kejadian BBLR $(p=0,713)$. Hasil penelitian di Yogyakarta juga mendapatkan bahwa umur ibu tidak berhubungan signifikan dengan kejadian BBLR dengan $p$-value $=0,117$ (Puspitasari 2014). Namun, hasil penelitian ini tidak didukung oleh beberapa penelitian, diantaranya hasil penelitian Demelash et al. (2015) yang menunjukkan bahwa usia ibu melahirkan $<20$ tahun berisiko tiga kali melahirkan BBLR (OR=3;95\%CI:1,65-5,73). Hasil penelitian Chaman et al. (2013) juga mendapatkan bahwa umur ibu hamil secara signifikan berhubungan dengan BBLR $(\mathrm{p}=0,01)$. Hasil penelitian Zahed et al. (2004) menyatakan bahwa umur ibu hamil diatas 35 tahun berisiko 2,3 kali melahirkan BBLR. Penelitian di Bali juga mendapatkan bahwa umur ibu kurang dari 20 tahun dan lebih dari 35 tahun akan mengalami kemungkinan 3,4 kali atau 77,0\% untuk melahirkan BBLR daripada kelompok umur 20 tahun sampai 35 tahun (Syahir 2015). Penelitian di neonatal intensive care unit (NICU) RSUP Prof.Dr.R.D. Kandou Manado menemukan adanya hubungan yang signifikan antara usia ibu hamil dengan kejadian BBLR $(\mathrm{p}=0,001)$ (Pinontoan \& Tombokan 2015).

Umur dikategorikan berisiko jika usia ibu hamil dan melahirkan di bawah 20 tahun atau di atas 35 tahun. Usia dibawah 20 tahun dikategorikan berisiko sebab secara anatomi dan fisiologi sistem reproduksi wanita belum sempurna, sehingga memberikan sejumlah risiko penyulit selama kehamilan dan persalinan sementara usia diatas 35 tahun dikategorikan berisiko sebab secara fisiologis ibu hamil rentan mengalami penyakit kronis seperti hipertensi, diabetes mellitus dan anemia. Fungsi reproduksi mengalami penurunan dibandingkan reproduksi normal, sehingga kemungkinan terjadinya komplikasi dan mengalami penyulit obstetrik (Cunningham 2012). Hasil penelitian ini tidak didukung oleh teori yang telah ada, hal ini dapat disebabkan oleh masih adanya faktor lain yang turut berpengaruh terhadap kejadian BBLR artinya bahwa usia ibu melahirkan bukanlah faktor tunggal penyebab BBLR. Selain itu, jumlah sampel yang relatif sedikit serta sebaran umur yang lebih sedikit pada kelompok umur berisiko dapat menjadi faktor penyebab variabel umur ibu tidak berhubungan dengan kejadian BBLR pada penelitian ini.

Analisis bivariat antara kejadian BBLR dengan pendapatan per bulan menunjukkan bayi BBLR dengan pendapatan keluarga kategori kurang, sebesar $18,6 \%$. Sementara balita yang dilahirkan tidak BBLR dengan pendapatan cukup sebesar $88,2 \%$. Uji chi square menunjukkan nilai $\mathrm{p}=0,709$. Hal ini menunjukkan bahwa tidak terdapat kaitan antara kejadian BBLR dengan pendapatan keluarga per bulan. Hasil penelitian ini sesuai dengan penelitian Mahayana et al. (2015) yang menyatakan bahwa tidak terdapat hubungan yang signifikan antara kejadian BBLR dengan status sosial ekonomi $(\mathrm{p}=0,990)$. Namun hasil penelitian ini tidak sesuai dengan hasil penelitian Demelash et al. (2015) bahwa pendapatan per bulan $<26$ dolar berisiko 3,8 kali melahirkan BBLR $(\mathrm{OR}=3,8)$. Penelitian di RSUP Dr. M. Djamil Padang menemukan bahwa status sosial ekonomi rendah $(54,3 \%)$ memiliki proporsi yang lebih besar pada kejadian BBLR (Mahayana et al. 2015). Hasil penelitian ini juga tidak sesuai dengan penelitian Joshi et al. (2007) yang mendapatkan bahwa terdapat hubungan yang signifikan antara pendapatan per bulan dengan kejadian BBLR $(\mathrm{p}<0,001)$.

Pendapatan rumah tangga berkaitan dengan permasalahan gizi seperti BBLR dan stunting. Penelitian Mauludyani et al. (2012) menyatakan bahwa pendapatan keluarga berhubungan dengan masalah gizi stunting. Pada ibu dengan status sosial ekonomi yang baik memungkinkan ibu hamil untuk berada dalam lingkungan yang lebih baik, seperti jauh dari paparan asap rokok dan bekerja berat. Keadaan sosial ekonomi yang baik juga dapat menjamin kecukupan zat gizi selama hamil untuk mendapatkan hasil akhir janin yang optimal. Status ekonomi 
yang rendah akan berdampak pada konsumsi bahan makanan dan pemanfaatan pelayanan kesehatan. Selain itu, keadaan sosio-ekonomi yang baik juga menjauhkan ibu hamil dalam keadaan stres yang dapat mengganggu keseimbangan hormonal ibu (Contrada et al. 2011). Hasil penelitian ini tidak didukung dengan teori yang ada, hal ini dapat disebabkan karena indikator status ekonomi yang digunakan hanya satu yakni pendapatan perbulan. Sementara masih ada beberapa hal yang turut mempengaruhi status ekonomi seperti kondisi tempat tinggal, jumlah anggota keluarga yang tinggal satu rumah, jumlah pengeluaran per bulan yang tidak diamati oleh peneliti.

Variabel tingkat pendidikan menunjukkan bahwa balita BBLR dengan pendidikan ibu yang rendah sebanyak 45,5\%. Sedangkan, kategori pendidikan ibu tinggi melahirkan bayi tidak BBLR sebanyak $89,8 \%$. Nilai $\mathrm{p}=0,017$ menunjukkan bahwa terdapat hubungan signifikan antara tingkat pendidikan dengan kejadian BBLR. Hal ini sesuai dengan hasil penelitian Demelash et al. (2015) yang menunjukkan bahwa pendidikan formal yang rendah berisiko enam kali melahirkan BBLR. Hal yang sama juga ditemukan pada hasil penelitian di Nepal yang menyatakan bahwa pendidikan ibu secara signifikan berhubungan dengan BBLR (Joshi et al. 2007). Penelitian yang dilakukan di Kota Sumenep juga menemukan bahwa pendidikan ibu rendah 4,4 kali berisiko melahirkan BBLR (Festy 2011). Namun, hasil penelitian Chaman et al. (2013) mendapatkan bahwa tidak terdapat hubungan yang signifikan antara tingkat pendidikan dengan kejadian BBLR. Penelitian Puspitasari (2014) juga menyatakan bahwa tidak terdapat hubungan signifikan antara tingkat pendidikan ibu dengan kejadian BBLR $(p=0,562)$.

Pendidikan mempengaruhi persepsi seseorang dalam berperilaku termasuk perilaku sehat seperti perilaku makan ibu dan pemanfaatan fasilitas kesehatan. Tingkat pendidikan ibu menggambarkan pengetahuan terkait kesehatan. Ibu dengan pendidikan tinggi kemungkinan memiliki tingkat pengetahuan tentang kesehatan yang juga tinggi, karena semakin mudah memperoleh informasi tentang kesehatan dibandingkan dengan yang berpendidikan rendah. Sebaliknya pendidikan yang kurang menghambat perkembangan seseorang terhadap nilai-nilai yang baru dikenal (Festy 2011).

\section{KESIMPULAN}

Berdasarkan hasil penelitian dapat disimpulkan bahwa balita BBLR dengan umur ibu berisiko sebanyak $27,3 \%$ dan kejadian BBLR ti- dak berhubungan dengan usia ibu melahirkan ( $\mathrm{p}$ $=0,371$ ), kejadian BBLR tidak berhubungan dengan pendapatan per bulan $(p=0,709)$, kejadian BBLR berhubungan dengan tingkat pendidikan ( $p$ $=0,017$ ). Pendidikan berperan dalam membentuk perilaku sehat wanita hamil yang akan berdampak terhadap bayi yang dilahirkan, sehingga perlu diadakan pendidikan gizi pada wanita usia subur dan wanita hamil yang diharapkan dapat memperbaiki outcome kehamilan. Diharapkan juga adanya penelitian yang mencakup variabel status sosial ekonomi yang tidak sebatas pendapatan perbulan tetapi manambahkan variabel kondisi tempat tinggal dan pengeluaran per bulan.

Penelitian ini memiliki sejumlah keterbatasan diantaranya jumlah subjek yang kecil dan subjek tidak seimbang antara jumlah subjek BBLR dan subjek normal. Pada variabel status sosial ekonomi hanya mengambil jumlah pendapatan, tanpa mempertimbangkan jumlah pengeluaran dan pembiayaan keluarga.

\section{DAFTAR PUSTAKA}

Chaman R, Amiri M, Raei M, Ajami ME, Sadeghian A, Khosravi A. 2013. Low birth weight and its related risk factors in Northeast Iran. Iran J Pediatr 23(6):701-704.

Cunningham FG. 2012. Obstetri Williams Cetakan 23. Jakarta: EGC.

Contrada RJ, Baum A. 2011. The Handbook of Stress Science: Biology, Psychology, and Health. New York: Springer Publishing Company.

Datar A, Jacknowitz A. 2009. Birth weight effects on children's mental, motor and physical development: evidence from twins data. Matern child health J 13(6):780-794.

Demelash H, Motbainor A, Nigatu D, Gashaw K, Melese A. 2015. Risk factors for low birth weight in Bale zone hospitals, South-East Ethiopia : case-control study. BMC Pregnancy \& Children 15(1):264-274.

Festy PW. 2011. Analisis Faktor Risiko pada Kejadian Berat Badan Lahir Rendah di Kabupaten Sumenep [skripsi]. Surabaya: Universitas Muhammadiyah Surabaya.

Gibney MJ, Margetts BM, Kaerney JM, Arab L. 2005. Gizi Kesehatan Masyarakat. Jakarta: EGC.

Goldenberg RL, Culhane JF. 2007. Low birth weight in the United States. Am J Clin Nutr 85(S):584-590.

Joshi HS, Srivastava PC, Agnihotri AK, Joshi MC, Chandra S, Mahajan V. 2007. Risk factors for low birth weight (LBW) babies 
and its medico-legal significance. J Indian Acad Forensic Med 32(3):212-215.

[Kemenkes RI] Kementerian Kesehatan Republik Indoensia. 2013. Riset Kesehatan Dasar. Jakarta: Kemenkes RI.

Mahayana SAS, Chundrayett E, Yulistini. 2015. Faktor Risiko yang Berpengaruh terhadap Kejadian Berat Badan Lahir Rendah di RSUP Dr.M.Djamil Padang. Jurnal Kesehatan Andalas 4(3):664-673.

Mauludyani AVR, Fahmida U, Santika. 2012. Undernutrition prevalence among children under two years old in Indonesia during Economic crisis and its related factors. J Gizi Pangan 7(3):169-174.

Mduduzin N, Mbuya M. 2010. Biological, social, and environmental determinants of low birth weight and stunting among infants and young children in Zimbabwe. Zimbabwe working paper 7:32-61.

Pinontoan VM \& Tombokan SGJ. 2015. Hubungan umur dan paritas ibu dengan kejadian berat badan lahir rendah. Jurnal ilmiah bidan 3(1):20-25.

Puspitasari R. 2014. Hubungan tingkat pendidikan dan pekerjaan ibu dengan kejadian bayi berat lahir rendah di RSU PKU Muhammadiyah Bantul (Skripsi). Yogyakarta: Sekolah Tinggi Ilmu Kesehatan 'Aisyiyah Yogyakarta.

Syahir A. 2015. Gambaran umur ibu, usia kandungan dan tinggi ibu terhadap kejadian Bayi Berat Lahir Rendah (BBLR) di Wilayah Puskesmas Gianyar 1 Bali 2015. Intisari Sains Medis 6(1):1-7.

Vir SC. 2011. Public health nutrition in developing countries. New Delhi: Woodhead Publishing.

Zahed PY, Esmaeili MR, Haji Ahmadi M. 2004. Effect of risk factors on low birth weight neonates. J Babol University Med Sci 22(6):18-24. 